\title{
Serum interleukin-15 levels in cancer patients with cachexia
}

\author{
PEDRO L. MARTÍNEZ-HERNÁNDEZ ${ }^{1}$, ÁNGEL HERNANZ-MACÍAS ${ }^{2}$, \\ CARMEN GÓMEZ-CANDELA ${ }^{3}$, CRISTINA GRANDE-ARAGÓN ${ }^{2}$, JAIME FELIU-BATLLE ${ }^{4}$, \\ JAVIER CASTRO-CARPEÑO ${ }^{4}$, ISABEL MARTÍNEZ-MUÑOZ ${ }^{2}$, LAURA ZURITA-ROSA ${ }^{3}$, \\ MARTA VILLARINO-SANZ ${ }^{3}$, CONCEPCIÓN PRADOS-SÁNCHEZ ${ }^{5}$ and JOAQUÍN SÁNCHEZ GARCÍA-GIRÓN ${ }^{6}$ \\ Departments of ${ }^{1}$ Internal Medicine, ${ }^{2}$ Biochemistry, ${ }^{3}$ Clinical Nutrition, ${ }^{4}$ Medical Oncology, \\ ${ }^{5}$ Pneumology, and ${ }^{6}$ Thoracic Surgery, La Paz University Hospital, E-28046 Madrid, Spain
}

Received May 14, 2012; Accepted July 2, 2012

DOI: $10.3892 /$ or.2012.1928

\begin{abstract}
Interleukin-15 (IL-15) has important anabolic effects on muscle protein metabolism through a decrease in the ATP-ubiquitin-dependent proteolytic pathway. The role of IL-15 in human cancer cachexia is unknown. The aim of this study was to assess the relationship between interleukin-15 (IL-15) in cancer patients with cachexia at diagnosis of malignancy and 8 weeks later. An observational study of 21 cancer patients (with and without cachexia) and 8 healthy subjects was conducted. Body composition was measured by leg-to-leg impedance. Serum IL-15 levels were assessed at baseline and after 4 and 8 weeks. Baseline IL-15 values were similar in cancer patients and in healthy subjects. Cancer patients with lower baseline levels of IL-15 $(<2 \mathrm{pg} / \mathrm{ml})$ had significantly higher fat mass (\%) along the study. Eighteen patients completed the study: five patients showed an increase of $3.7 \mathrm{~kg}$ at the end of the study (5.4\% of body weight) and showed a mean increase of IL-15 of $1.32 \mathrm{pg} / \mathrm{ml}(121 \%)$ at 4 weeks and $2.32 \mathrm{pg} / \mathrm{ml}(197 \%)$ at 8 weeks, as compared with mean decrease of $-4.1 \mathrm{~kg}(-5.3 \%)$ and $-0.09 \mathrm{pg} / \mathrm{ml}(-2.5 \%)$ and $0.6 \mathrm{pg} / \mathrm{ml}(40.8 \%)$ in the 13 patients who lost weight $(\mathrm{P}=0.001$ and $\mathrm{P}=0.022$, respectively). Changes of IL-15 at 4 and 8 weeks were directly associated with changes in body weight, body mass index (BMI), fat-free mass and muscle mass $(\mathrm{P}<0.05)$, and indirectly associated with percentage of weight loss $(\mathrm{P}<0.05)$. In summary, although the results indicate that IL-15 does not have a role in cancer cachexia pathogenesis, the association during evolution between serum IL-15 and changes in weight and muscle mass suggests a possible role of IL-15 as a marker of the body composition response in cancer patients who are losing weight at the time of diagnosis.
\end{abstract}

Correspondence to: Dr Pedro L. Martínez-Hernández, Department of Internal Medicine, La Paz University Hospital, Paseo Castellana 261, E-28046 Madrid, Spain

E-mail: plmartinez.hulp@salud.madrid.org

Key words: muscle mass, body weight, cachexia, cancer, fat-free mass, interleukin-15

\section{Introduction}

Cancer-associated cachexia in addition to producing intense anorexia, asthenia, and anemia is characterized by weight loss and loss of skeletal muscle mass with or without loss of fat mass (1-4). Cancer cachexia is a multidimensional and multifactorial syndrome, the underlying pathophysiology of which is complex and incompletely defined. Although the prevalence of cancer cachexia varies by tumor type, it occurs in $15-40 \%$ of all cancer patients at the time of diagnosis and in $60-80 \%$ of patients with advanced disease (5). The presence of cachexia is associated with deterioration in the quality of life, decreased functioning, and higher mortality. It is thought that in cancer, $>30 \%$ of patients die due to cachexia and $>50 \%$ of patients with cancer die with cachexia being present (6).

Interleukin-15 (IL-15) is a multifunctional cytokine originally identified in media conditioned by a monkey kidney epithelial cell line (CV-1/EBNA) (7). IL-15 induces proliferation of $\mathrm{T}$ cells (8) and shares many biological activities with IL-2 since its functions are mediated through the $\beta$ and $\gamma$ chains of the IL-2 receptor (9). However, unlike IL-2, which is produced almost exclusively by activated T cells, the IL-15 gene is not expressed in these cells, but rather IL-15 mRNA has been detected in placenta, skeletal muscle, kidney, lung and heart (7). IL-15 can stimulate differentiated myocytes and muscle fibres to accumulate increased amounts of contractile proteins, suggesting that IL-15 may play a role in skeletal muscle fibre growth (10). In cultured skeletal myogenic cells, IL-15 action is distinct from insulin-like growth factor-I (IGF-I). Overexpression of IL-15 induces hypertrophy of skeletal muscle through stimulation of protein synthesis and inhibition of protein degradation (11). In a rat model of cancer cachexia, IL-15 antagonizes muscle protein waste by decreasing protein degradative rates without affecting protein synthesis. These anabolic effects of IL-15 were associated with an inhibition of the ATP-ubiquitin-dependent proteolytic pathway (12). Moreover, IL-15 was able to suppress the increased DNA fragmentation and to suppress several apoptosis pathways, including tumor necrosis factor- $\alpha$ (TNF- $\alpha$ ) signaling pathway and reduction of inducible nitric oxide synthase (iNOS) responsible for the synthesis of nitric oxide (NO) $(13,14)$. These observations support the anabolic effect 
of IL-15 on skeletal muscle. For these reasons, and given that expression of mRNA is encoded by the IL-15 gene in skeletal muscle is increased in cancer, it has been postulated that IL-15 may act as an anti-cachexia cytokine preserving muscle mass and weight loss in animals bearing an experimental model of cachexia (15).

Increased protein degradation rates in skeletal muscles are associated with muscle wasting in cancer patients, and inhibition of protein degradation induced by IL-15 may contribute to preserve muscle mass in cancer patients with cachexia. The objective of this study was to assess the role of IL-15 in cancer patients with cachexia at diagnosis of malignancy and during the course of the disease.

\section{Subjects and methods}

Study population. Between November 2008 and September 2009 , an observational study was performed in cancer patients attended in the Service of Oncology of Hospital Universitario La Paz in Madrid, Spain. At the time of diagnosis of malignancy, patients were divided into those with cachexia and those without cachexia. Patients were included in the group with cachexia if they had lost $\geq 10 \%$ of their preillness stable weight during the previous 6 months, serum C-reactive protein $(\mathrm{PCR}) \geq 10 \mathrm{mg} / \mathrm{l}$, and caloric ingestion of $\leq 1,500 \mathrm{kcal}$ a day in a 72-h nutritional survey. All patients aged between 18 and 65 years were included in the study. A life expectancy $>8$ weeks was also required as well as a recent diagnosis of oncologic disease and no previous cancer therapy except for palliative treatment of pain. The study was approved by the Ethics Committee of the hospital. Written informed consent was obtained from all patients.

Exclusion criteria were as follows: life expectancy $<8$ weeks; current nutritional treatment or weight loss diet; swallowing difficulty or partial or complete obstruction due to a digestive tract tumor; diabetes mellitus; acute or chronic inflammatory disease; any type of chronic disease associated with the development of cachexia [such as, congestive heart failure, severe chronic obstructive pulmonary disease (COPD), advanced chronic renal failure, human immunodeficiency virus (HIV-1) infection, endocrine disorders]; diseases causing malnutrition or malabsorption; acute infections; carriers of pacemakers; and patients with moderate-severe depression, substance use, or psychiatric disorders that were considered ineligible by the attending physician.

Also, healthy subjects aged 18-65 years were asked for participation in the study. They were retrospectively selected among patients with mild health conditions attended in the outpatient clinics of the Service of Internal Medicine during the year prior to the study. It was tried to select individuals of a similar age ( \pm 5 years) and gender than cancer patients being recruited. Other inclusion criteria were stable weight during the previous 6 months, BMI between 20 and $29.9 \mathrm{~kg} / \mathrm{m}^{2}$, and absence of oncologic history, current nutritional treatment, weight loss diet, and acute or chronic inflammatory or infectious disease.

Procedures. Patients were assessed after diagnosis, before the commencement of treatment (baseline visit) and at 4 and 8 weeks later. After the baseline visit, patients were treated (surgery, chemotherapy, radiotherapy, or nutritional support) according to individual treatment plans of the Service of Oncology. At the baseline and subsequent visits the following data were recorded: demographics, salient features of medical history, oncologic diagnosis, TNM stage, drug treatment, Eastern Cooperative Oncology Group (ECOG) performance status (16), self-reported duration of weight loss and weight loss percentage [self-reported habitual stable weight (in $\mathrm{kg}$ ) - current weight (in $\mathrm{kg}$ ) divided by habitual weight (in $\mathrm{kg}$ ) $\mathrm{x}$ 100]. Weight and height were adjusted to the nearest $0.1 \mathrm{~kg}$ and $0.01 \mathrm{~cm}$ using a calibrated scale (Seca 780, Vogel \& Halke GmbH \& Co., Hamburg, Germany).

At each visit, a physical examination was performed and body composition was measured by bioelectrical impedance (leg-to-leg impedance) using the Tanita body fat analyzer (model BC-420MA, Biologica Tecnologia Medica, S.L., Barcelona, Spain) following the protocol described by Utter et al (17). Dietary data for the previous $72 \mathrm{~h}$ were collected. Patients were assessed for appetite according to response to the question 'How do you assess your current level of appetite?' using a 100-mm visual analog scale (VAS). Asthenia was evaluated according to a validated linear analog cancer scale developed by the Asthenos Group (18), based on responses to the three questions ('How would you rate your level of energy over the past week?', 'How would you rate your level of ability to perform daily activities over the past week?' and 'How would you rate your quality of life over the past week?') graded from 0 to 100 . Muscle function was assessed using a Smedley hand grip dynamometer and the treadmill 6-min walk test (19).

Laboratory tests. Laboratory tests were carried out at baseline and at 4 and 8 weeks, including complete blood cell count and standard biochemical profile, inflammatory markers (sedimentation rate, serum CRP), thyroid hormones (only at the baseline), nutritional markers (serum albumin, total proteins, transferrin and total lymphocytes), creatine phosphokinase (CPK) and myoglobin. Amino acids were measured by high-resolution liquid chromatography using Pico-Tag Station (Waters Associates, Milford, MA, USA). Baseline insulin levels were measured by a fluoroimmunometric assay (AIA-360 Tosoh Bioscience, San Francisco, CA, USA) and serum cortisol by immunofluorescence (Immulite 2500, Siemens Healthcare Diagnostics, UK). Insulin resistance was detected by the quantitative insulin sensitivity check index (QUICKI) (20). Plasma concentrations of IL-15 and TNF- $\alpha$ receptor II (sTNF-RII) were measured by enzyme immunoassay (Quantikine, R\&D Systems, Minneapolis, MN, USA).

Healthy subjects also attended the three clinical visits and underwent the same clinical studies and laboratory tests.

Statistical analysis. Data were analyzed with the SAS (version 9.1) statistical software program (SAS Institute, Cary, $\mathrm{NC}$, USA). Categorical variables are expressed as frequency and percentages, and continuous variables as mean and standard deviation (SD) or median and range (minimum, maximum) according to the distribution of data. Baseline categorical variables were compared with the Fisher's exact test and quantitative variables with the Mann-Whitney U 
Table I. Baseline characteristics of cancer patients and healthy controls.

\begin{tabular}{|c|c|c|c|c|}
\hline \multirow[b]{2}{*}{ Variable } & \multicolumn{3}{|c|}{ Cancer patients } & \multirow[b]{2}{*}{$\begin{array}{c}\text { Healthy } \\
\text { subjects }(n=8)\end{array}$} \\
\hline & $\begin{array}{c}\text { All } \\
\text { patients }(n=21)\end{array}$ & $\begin{array}{c}\text { Group A } \\
\% \mathrm{WL}<10 \%(\mathrm{n}=13)\end{array}$ & $\begin{array}{c}\text { Group B } \\
\% \mathrm{WL} \geq 10 \%(\mathrm{n}=8)\end{array}$ & \\
\hline Age (years) & $50.2 \pm 10.2$ & $52.1 \pm 10.5$ & $47.1 \pm 9.5$ & $47.1 \pm 12.9$ \\
\hline Gender, males (\%) & $19(90.5)$ & $11(84.5)$ & $8(100)$ & $4(50)$ \\
\hline Weight (kg) & $75.1 \pm 12.1$ & $75.91 \pm 12.9$ & $73.8 \pm 11.2$ & $68.9 \pm 7.3$ \\
\hline Height (m) & $1.72 \pm 0.06$ & $1.7 \pm 0.54$ & $1.75 \pm 0.76^{\mathrm{a}}$ & $1.66 \pm 0.83$ \\
\hline Body mass index $\left(\mathrm{kg} / \mathrm{m}^{2}\right)$ & $25.3 \pm 3.9$ & $26.2 \pm 4.4$ & $23.9 \pm 2.9$ & $25.2 \pm 3.6$ \\
\hline Weight loss (\%) & $7.2 \pm 5.4^{\mathrm{b}}$ & $3.7 \pm 3.5^{\mathrm{b}}$ & $12.7 \pm 2.4^{\mathrm{b}, \mathrm{c}}$ & $-0.3 \pm 2.2$ \\
\hline Duration of weight loss (days) & $80.1 \pm 66.1$ & $58.1 \pm 62.8$ & $104.7 \pm 64.5$ & NA \\
\hline \multicolumn{5}{|l|}{ Body composition } \\
\hline Fat mass $(\%)$ & $22.2 \pm 6.72$ & $24.3 \pm 7.4$ & $18.8 \pm 3.7^{\mathrm{a}}$ & $27.7 \pm 8.7$ \\
\hline Fat mass (kg) & $16.7 \pm 6.4$ & $18.3 \pm 7.1$ & $14.1 \pm 4.1$ & $18.4 \pm 6.1$ \\
\hline Fat-free mass (kg) & $58.2 \pm 8.7^{\mathrm{a}}$ & $57.3 \pm 9.4$ & $59.5 \pm 7.9^{\mathrm{a}}$ & $48.9 \pm 10.1$ \\
\hline Muscle mass (kg) & $55.2 \pm 8.4^{\mathrm{a}}$ & $54.3 \pm 9$ & $56.6 \pm 7.6^{\mathrm{a}}$ & $46.4 \pm 9.5$ \\
\hline Appetite, visual analog scale (mm) & $55.6 \pm 18.2^{b}$ & $56 \pm 20.5^{\mathrm{a}}$ & $49.6 \pm 14.2^{b}$ & $79.4 \pm 15.2$ \\
\hline \multicolumn{5}{|l|}{ Cancer linear analog scale (mm) } \\
\hline Energy & $54.4 \pm 21.5$ & $54.6 \pm 23.9$ & $54 \pm 18.6$ & $70.6 \pm 17.4$ \\
\hline Ability to perform daily activities & $68.5 \pm 20.3$ & $65.8 \pm 22.7$ & $72.7 \pm 15.9$ & $76.9 \pm 24.1$ \\
\hline Quality of life & $56.1 \pm 23.3^{\mathrm{a}}$ & $60.7 \pm 24$ & $48.5 \pm 21.3^{\mathrm{a}}$ & $78 \pm 21.6$ \\
\hline Nutritional survey (72-h, Kcal/day) & $2142.6 \pm 561.7$ & $2097.4 \pm 577.9$ & $2194.3 \pm 583.7$ & $1874.7 \pm 339.2$ \\
\hline \multicolumn{5}{|l|}{ Muscle tests } \\
\hline Handgrip dynamometer (kg) & $41.6 \pm 7.7$ & $41.6 \pm 9.3$ & $41.6 \pm 4.7$ & $35 \pm 10.2$ \\
\hline Treadmill 6-min walk (m) & $410.6 \pm 87.1$ & $436.3 \pm 87.3$ & $368.7 \pm 73.44^{\mathrm{a}}$ & $473.6 \pm 56.8$ \\
\hline
\end{tabular}

Data are the mean \pm standard deviation unless otherwise stated; NA, not applicable; $\%$ WL, \% weight loss. ${ }^{\text {a }}<<0.05$ and ${ }^{b} \mathrm{P}<0.001$ as compared with healthy subjects; ${ }^{\mathrm{P}}<0.01$ group A vs. group B.

test. Two-way analysis of variance (ANOVA) for repeated measures with group and time (baseline, week 4, week 8) as the two factors was performed. The main effect (mean values obtained in each group or mean value at each time point) and the interaction between factors (a significant interaction indicated that group profiles were different) was considered. This analysis was performed according to the following groups: i) percentage of weight loss, ii) baseline IL-15 concentration, and iii) net weight loss or weight gain at the end of the study. The strength of the association between variables was assessed with the Pearson's correlation coefficient. Statistical significance was set at $\mathrm{P}<0.05$.

\section{Results}

Study subjects. A total of 83 patients with a recent diagnosis of cancer were attended during the study period. However, 62 patients were excluded because of lack of fulfilment of the inclusion criteria in 53 and refusal to take part in the study in 9 . Therefore, the study population included 21 cancer patients $(90.5 \%$ males) with a mean age of $50.2 \pm 10.2$ years (range, 23-65 years). Eight healthy subjects (50\% males) with a mean age of $47.1 \pm 12.9$ years were selected. The percentage of women was significantly lower among cancer patients than among in healthy subjects (9.5 vs. $50 \%, \mathrm{P}=0.033$ ).

Baseline data and serum IL-15 levels. There were 13 cancer patients without cachexia (group A) and 8 with cachexia (group B). In group A, one patient with pancreatic cancer died in the first week after insertion of a biliary stent and another with lung cancer discontinued the study voluntarily before week 4. In group $\mathrm{B}$, one patient with cancer of unknown origin died at week 6 due to hydropic decompensation and hepatic encephalopathy. A total of 11 patients in group A, 7 patients in group B, and the 8 health subjects completed the study.

Lung cancer was diagnosed in 13 patients (a patient had a maxillofacial neoplasm simultaneously), colorectal cancer in 3 , esophageal cancer in 2, T-cell lymphoma in 1 , pancreatic cancer in 1, and unknown origin in 1. Stage IV disease was diagnosed in 8 patients, stage III in 8 , stage II in 4 and stage I in 1 . ECOG performance status was 0 in 11 patients and 1 in the remaining 10 . The distribution of patients by tumor site, cancer stage, and ECOG grade was similar in groups A and B. Clinical characteristics of the study population at baseline are shown in Table I. There were statistically significant differences between cancer patients and healthy subjects in weight 
Table II. Baseline laboratory data in cancer patients and healthy controls.

Cancer patients

\begin{tabular}{cccc}
\hline All & Group A & Group B & Healthy \\
patients $(\mathrm{n}=21)$ & $\% \mathrm{WL}<10 \%(\mathrm{n}=13)$ & $\% \mathrm{WL} \geq 10 \%(\mathrm{n}=8)$ & subjects $(\mathrm{n}=8)$
\end{tabular}

Variable

patients $(n=21)$

$1.89 \pm 1.08$
$3733.1 \pm 996.2$
$18.7 \pm 8.4$
$10.9 \pm 12.4$
$96 \pm 14$
$0.35 \pm 0.03$

$44.3 \pm 46.9^{\mathrm{b}}$

$34.1 \pm 24.1^{\mathrm{c}}$

$57.6 \pm 32.4^{\mathrm{b}}$

$3.6 \pm 0.5^{\mathrm{e}}$
$212.86 \pm 49^{\mathrm{c}}$
$2083 \pm 821$
$976.2 \pm 151.5$
$46.3 \pm 11.1^{\mathrm{d}}$
$119.3 \pm 50.4$
$81.8 \pm 15.1^{\mathrm{d}}$
$140.6 \pm 21.9^{\mathrm{d}}$
$66.9 \pm 9^{\mathrm{c}}$
$49.1 \pm 11.1$
$1802.8 \pm 322.8$
$95.2 \pm 32.1^{\mathrm{b}}$
$119.9 \pm 24.8$
$228.7 \pm 98.8$

$180.7 \pm 43.8$
$39.5 \pm 13.1^{\mathrm{d}}$
$119.9 \pm 40.9$
$116.9 \pm 41.3$

$20.8 \pm 12.7$

$1.98 \pm 0.99$
$3694.3 \pm 1026.9$
$19.8 \pm 9.1$
$12.3 \pm 15.5$
$102.2 \pm 15.6$
$0.35 \pm 0.05$

$36.4 \pm 44.2^{\mathrm{b}}$

$31.4 \pm 22.9^{\mathrm{c}}$

$22.8 \pm 8.3$

$71.9 \pm 28.3^{\mathrm{d}}$

Nutritional biochemistry

Albumin $(\mathrm{g} / \mathrm{dl})$
Transferrin $(\mathrm{mg} / \mathrm{dl})$
Lymphocytes $\left(\right.$ cells $\left./ \mathrm{mm}^{3}\right)$
Essential amino acids $(\mu \mathrm{mol} / \mathrm{l})$
Histidine
Treonine
Isoleucine
Leucine
Phenylalanine
Tryptophan

Non-essential amino acids ( $\mu \mathrm{mol} / \mathrm{l})$

Glutamic acid

Serine

Proline

Lipid profile

Total cholesterol (mg/dl)

HDL-C

LDL-C

Triglycerides

$3.5 \pm 0.5^{\mathrm{d}}$
$219.4 \pm 49.4^{\mathrm{b}}$
$2043 \pm 682$
$957.3 \pm 127.7$
$47.7 \pm 10.5$
$106.1 \pm 35.1^{\mathrm{d}}$
$79.1 \pm 9.2$
$138.5 \pm 23.5$
$69.1 \pm 9.2^{\mathrm{c}}$
$50.7 \pm 8$
$1724.4 \pm 221.7$
$90.1 \pm 29.1^{\mathrm{b}}$
$116 \pm 23.8$
$201.9 \pm 44.9$

$190.9 \pm 50.7$
$42.2 \pm 13.75$
$127.2 \pm 47.3$
$125.1 \pm 46.1$

$1.77 \pm 1.27$
$3796.2 \pm 1010.1$
$16.9 \pm 7.2$
$8.6 \pm 4.3$
$88.4 \pm 8.3^{\mathrm{a}}$
$0.35 \pm 0.02$

$57.1 \pm 51.4^{\mathrm{c}}$

$38.4 \pm 27.1^{\mathrm{d}}$

$17.5 \pm 17.9^{\mathrm{a}, \mathrm{d}}$

$38.6 \pm 29.1^{\mathrm{a}, \mathrm{e}}$

$3.5 \pm 0.4^{\mathrm{c}}$
$202.2 \pm 49.8^{\mathrm{d}}$
$2148 \pm 1059$
$1006.8 \pm 189.5$
$44.1 \pm 12.5^{\mathrm{d}}$
$140.9 \pm 65.4$
$86.1 \pm 21.7$
$144 \pm 20$
$63.5 \pm 8^{\mathrm{d}}$
$46.4 \pm 13$

$1930.1 \pm 428.5$

$103.5 \pm 36.8^{\mathrm{b}}$

$126.4 \pm 26.6$

$272.2 \pm 144.6$

$$
\begin{array}{r}
164.1 \pm 20.1^{\mathrm{d}} \\
34 \pm 10.6^{\mathrm{d}} \\
105.3 \pm 19.7 \\
100.7 \pm 25.4
\end{array}
$$

\section{$1.75 \pm 0.41$ \\ $3091 \pm 1061.1$ \\ $17.5 \pm 4.3$ \\ $5.4 \pm 2.5$ \\ $95 \pm 6.2$ \\ $0.38 \pm 0.03$}

\author{
$3.2 \pm 1.6$ \\ $10 \pm 7.4$ \\ $27.1 \pm 8.6$ \\ $148.9 \pm 98.3$
}

$4.3 \pm 0.4$

$267.6 \pm 24.2$

$2166 \pm 593$

$941.5 \pm 81.9$

$55.4 \pm 7.1$

$130.7 \pm 29.1$

$69.2 \pm 10.8$

$120.7 \pm 17.9$

$55 \pm 6.9$

$54.6 \pm 8.8$

$1748.4 \pm 140.3$

$47.2 \pm 10.3$

$108.2 \pm 18.3$

$221.2 \pm 90.4$

$220.4 \pm 45.8$

$55.6 \pm 14.3$

$137.5 \pm 37.9$

$108.7 \pm 70.3$

Data are the mean \pm standard deviation; $\%$ WL, \% weight loss; ${ }^{\mathrm{P}}<0.05$ group A vs. group $\mathrm{B} ;{ }^{\mathrm{b}} \mathrm{P}<0.001,{ }^{\mathrm{c}} \mathrm{P}<0.005,{ }^{\mathrm{d}} \mathrm{P}<0.05,{ }^{\mathrm{e}} \mathrm{P}<0.01 \mathrm{vs}$. healthy subjects.

loss, body fat mass, fat-free mass, and VAS score for appetite and quality of life.

Baseline laboratory data are summarized in Table II. In comparison with healthy subjects, cancer patients had significantly higher values of serum CRP, sedimentation rate, isoleucine, leucine, phenylalanine and glutamic acid, and significantly lower values of CPK, albumin, transferrin, histidine and high-density lipoprotein (HDL) cholesterol. Serum IL-15 concentrations were similar in cancer patients and healthy subjects as well as in cancer patients with and without cachexia. In the group of cancer patients, differences in IL-15 concentrations according to age, gender, cancer site (lung vs. gastrointestinal tract), cancer stage, ECOG status, weight or BMI subgroups were not observed (data not shown). However, in the subgroup of cancer patients with fat mass (FM\%) $<20 \%$ $(n=8)$ showed higher values of IL-15 than subgroup of patients with FM\% $\geq 30 \%$ ( $\mathrm{n}=4)$ : $(2.4 \pm 0.3$ vs. $1.2 \pm 0.7 \mathrm{pg} / \mathrm{ml}, \mathrm{P}=0.008)$. At baseline, there was a significant relationship between serum IL-15 and sTNF-RII ( $\mathrm{r}=0.619, \mathrm{P}=0.004)$.

Bodyweight and serum IL-15 levels at 4 and 8 weeks. Treatment of the patients included chemotherapy in 13 , surgery in 9 , and 

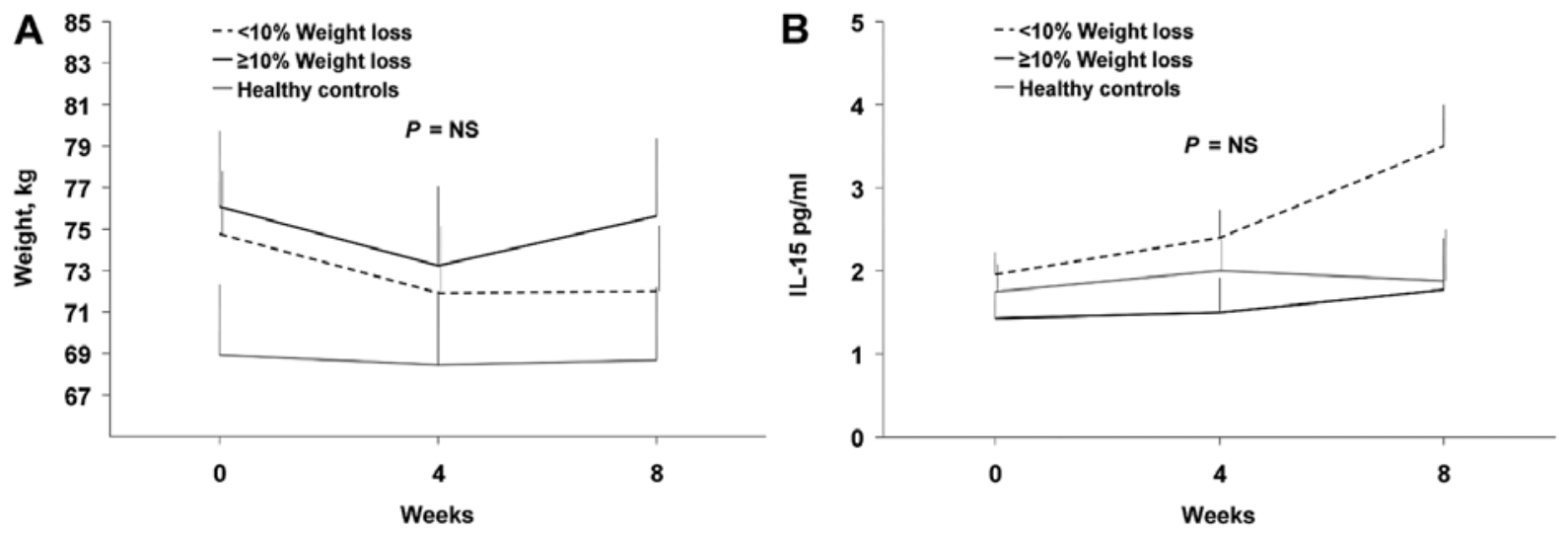

Figure 1. Body weight (A) and serum IL-15 (B) at 4 and 8 weeks in cancer patients and healthy subjects.

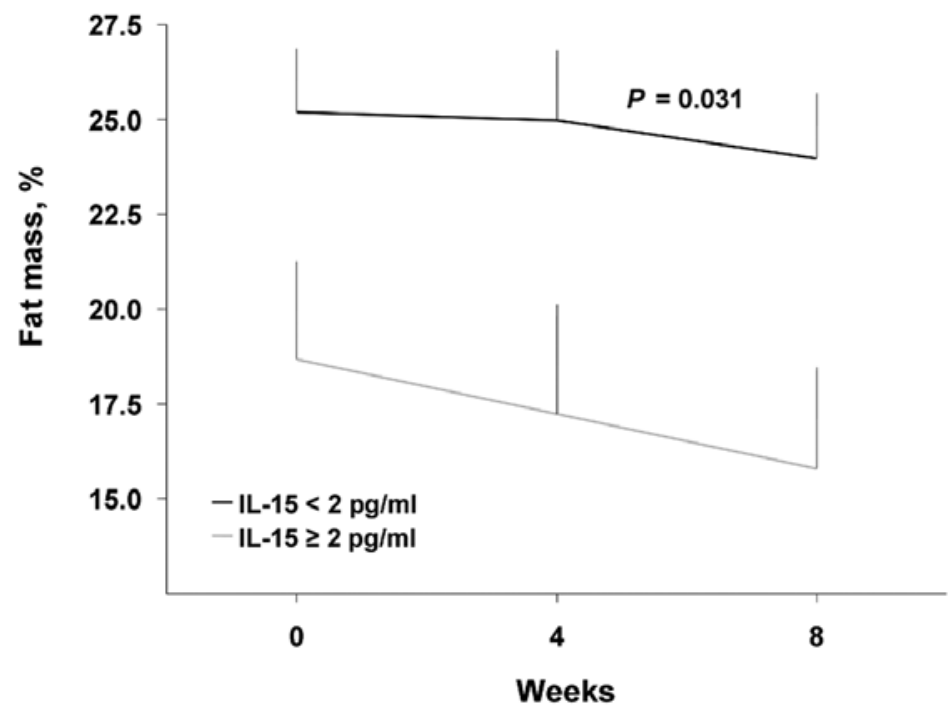

Figure 2. Fat mass (\%) at 4 and 8 weeks in cancer patients according to baseline IL-15 levels ( $<2 \mathrm{vs.} \geq 2 \mathrm{pg} / \mathrm{ml})$.

palliative care in 8 . All patients received dietary counseling. Dietary treatment was recommended to 10 patients. Nine patients received nutritional supplements, and one patient in group B received postoperative enteral nutrition through the nasogastric tube.

Throughout the study, differences in weight or serum IL-15 concentrations between cancer patients and healthy controls, and between groups $\mathrm{A}$ and $\mathrm{B}$ and healthy controls were not significant (Fig. 1).

When cancer patients were divided according to baseline IL-15 concentrations $<2 \mathrm{pg} / \mathrm{ml}$ or $\geq 2 \mathrm{pg} / \mathrm{ml}$, those with IL-15 levels $<2 \mathrm{pg} / \mathrm{ml}$ showed higher values fat mass, albumin, transferrin and amino acids, and lower values of caloric ingestion, sTNF RII, sedimentation rate, and myoglobin throughout the study period than patient with IL-15 concentrations $\geq 2 \mathrm{pg} / \mathrm{ml}$ $(\mathrm{P}<0.05)$ (Fig. 2).

A total of 18 cancer patients (group $A, n=11$; group $B, n=7$ ) completed the study. In 13 patients (group $\mathrm{A}, \mathrm{n}=8$; group $\mathrm{B}$, $\mathrm{n}=5)$, the mean weight loss was $4.1 \pm 1.2 \mathrm{~kg}(-5.3 \%)$ and in the remaining 5 patients (group $\mathrm{A}, \mathrm{n}=3$; group $\mathrm{B}, \mathrm{n}=2$ ), the mean weight gain was $3.7 \pm 1.8 \mathrm{~kg}(5.4 \%)$ as compared with baseline $(\mathrm{P}=0.001)$. Patients who had gained weight at the end of the study showed an increase in serum IL-15 concentrations significantly higher than patients who had lost weight either at week $4[1.32 \pm 0.47 \mathrm{pg} / \mathrm{ml}(121 \%)$ vs. $-0.09 \pm 0.29 \mathrm{pg} / \mathrm{ml}(-2.5 \%)]$ and at week 8 [2.32 $\pm 0.83 \mathrm{pg} / \mathrm{ml}(197 \%)$ vs. $0.6 \pm 0.51 \mathrm{pg} / \mathrm{ml}(40.8 \%)]$ $(\mathrm{P}=0.022)$ (Fig. 3). In the subset of 5 patients with weight gain, baseline IL-15 concentrations $<2 \mathrm{pg} / \mathrm{ml}$ were found in 4 and $\geq 2 \mathrm{pg} / \mathrm{ml}$ in 1 . None of these patients were treated surgically as compared with 8 patients with weight loss at the end of the study $(\mathrm{P}=0.036)$. These patients were treated with a higher average of chemotherapy cycles compared with patients with weight loss at the end of the study, patients who lost weight without surgical treatment and patients who lost weight and received surgical treatment $(3.6 \pm 0.2$ vs. $1.5 \pm 0.4$ vs. $2.2 \pm 0.6$ vs. $1.1 \pm 0.4$ cycles of chemotherapy; $\mathrm{P}=0.004, \mathrm{P}=0.032, \mathrm{P}=0.004)$ (Table III).

Two patients with lung cancer who had lost weight at the end of the study developed lower limbs edema. Chemotherapy or surgical treatment were not associated with an increase in total body water (\% or kgr).

Serum IL-15 levels and body composition. Serum IL-15 levels at 4 and 8 weeks were indirectly associated with percentage 

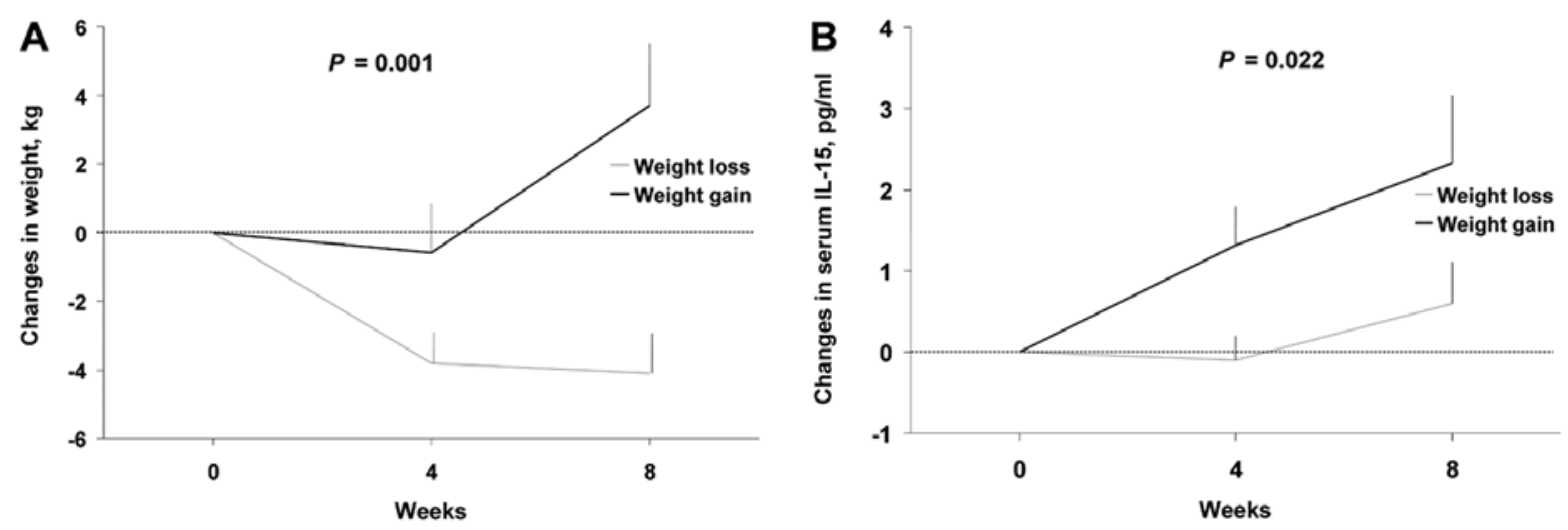

Figure 3. Changes in weight (A) and changes in serum IL-15 (B) among 18 patients who completed the study in relation to weight loss ( $\mathrm{n}=13$ ) or weight gain $(\mathrm{n}=5)$ at week 8 .

Table III. Treatments in 18 cancer patients who completed the study in relation to weight loss or weight gain at week 8 .

\begin{tabular}{lccc}
\hline Variables & Weight loss $(\mathrm{n}=13)(\%)$ & Weight gain $(\mathrm{n}=5)(\%)$ & P-value \\
\hline Chemotherapy, N (\%) & $8(61.5)$ & $5(100)$ & NS \\
Cycles of chemotherapy $^{\mathrm{a}}$ & $1.54 \pm 0.4$ & $3.6 \pm 0.2$ & 0.004 \\
Surgery, N (\%) & $8(61.5)$ & $0(0)$ & 0.036 \\
Dietary treatment, N (\%) & $5(38.5)$ & $3(60)$ & NS \\
Nutritional supplements, N (\%) & $4(30.1)$ & $3(60)$ & NS \\
Enteral nutrition, N (\%) & $1(7.7)$ & $0(0)$ & NS \\
Palliative care & $6(46.2)$ & $1(20)$ & NS \\
\hline
\end{tabular}

NS, not significant; ${ }^{a}$ mean \pm standard deviation.

Table IV. Correlations in cancer patients between changes of serum IL-15 concentrations at 4 and 8 weeks as compared with baseline, and similar changes in body composition.

\begin{tabular}{lll}
\hline Variables & \multicolumn{1}{c}{ Week 4} & Week 8 \\
\hline IL-15 and weight $(\mathrm{kg})$ & $\mathrm{r}=0.577, \mathrm{P}=0.01$ & $\mathrm{r}=0.58, \mathrm{P}=0.015$ \\
$\mathrm{IL}-15$ and $\mathrm{BMI}\left(\mathrm{kg} / \mathrm{m}^{2}\right)$ & $\mathrm{r}=0.575, \mathrm{P}=0.01$ & $\mathrm{r}=0.575, \mathrm{P}=0.0161$ \\
IL-15 and \% weight loss & $\mathrm{r}=-0.548, \mathrm{P}=0.015$ & $\mathrm{r}=-0.662, \mathrm{P}=0.004$ \\
IL-15 and fat-free mass $(\mathrm{kg})$ & $\mathrm{r}=0.514, \mathrm{P}=0.029$ & $\mathrm{r}=0.535, \mathrm{P}=0.027$ \\
IL-15 and muscle mass $(\mathrm{kg})$ & $\mathrm{r}=0.517, \mathrm{P}=0.023$ & $\mathrm{r}=0.541, \mathrm{P}=0.025$
\end{tabular}

BMI, body mass index.

of weight loss: $(\mathrm{r}=-0.508, \mathrm{P}=0.026)$ and $(\mathrm{r}=-0.657, \mathrm{P}=0.004)$ (Fig. 4). Changes in serum IL-15 levels at 4 and 8 weeks as compared with baseline values were directly associated with changes in body weight, BMI, fat-free mass, and muscle mass $(\mathrm{P}<0.05)$ and indirectly with percentage of weight loss $(\mathrm{P}<0.05)$ (Table IV). Changes at 8 weeks were directly associated with percentage of fat mass $(\mathrm{r}=0.485, \mathrm{P}=0.048)$ and fat mass (in $\mathrm{kg}$ ) $(\mathrm{r}=0.488, \mathrm{P}=0.047)$ and indirectly with serum CRP $(\mathrm{r}=-0.508$, $\mathrm{P}=0.032)$, basal cortisol $(\mathrm{r}=-0.6, \mathrm{P}=0.008)$, and lymphocytes $(r=-0.542, P=0.02)$.

\section{Discussion}

This study shows that in middle-age adults with newly diagnosed cancer and weight loss there was no difference in serum IL-15 levels as compared with healthy subjects. Moreover, there was no difference in serum IL-15 levels between groups $\mathrm{A}$ and $\mathrm{B}$ and healthy subjects. However, cancer patients with baseline IL-15 concentrations $<2 \mathrm{pg} / \mathrm{ml}$ showed a better preservation of fat mass, had a better nutritional status, and greater ability to regain weight at the end of the study. Moreover, 


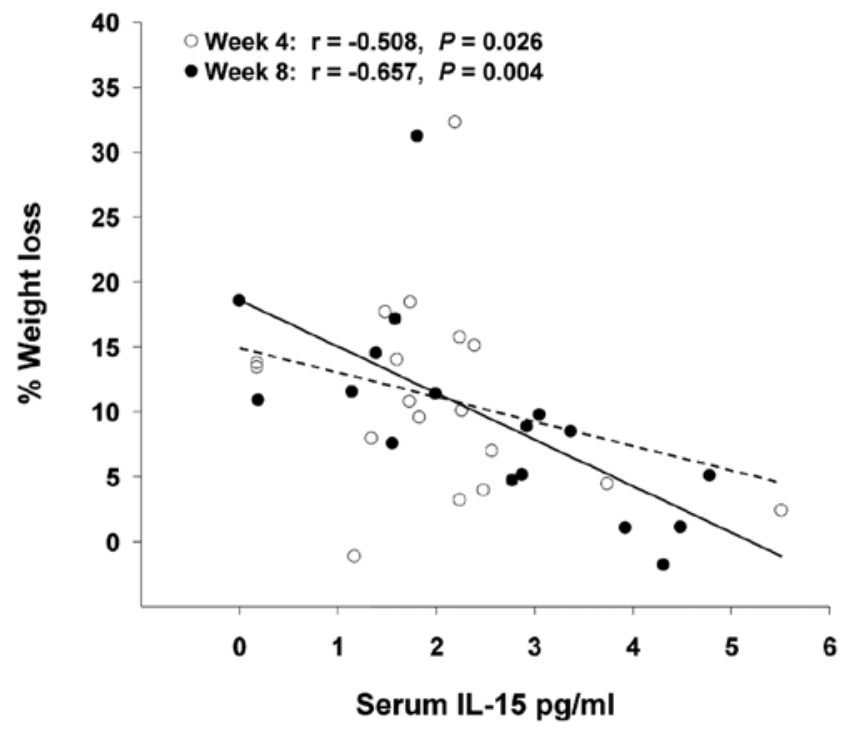

Figure 4. Correlations between serum IL-15 concentrations and percentage of weight loss at 4 and 8 weeks in cancer patients.

patients who gained weight showed an increase in IL-15 values at 4 and 8 weeks as compared with baseline levels as well as in comparison with patients who lost weight. The findings at baseline, initially, suggest that IL-15 is not implicated in the pathogenic mechanisms of cachexia in cancer patients. Nevertheless, in the evolution, the increase in IL-15 values in patients who gained weight and the direct association observed between IL-15 levels, body weight, and muscle mass suggest that there is a relation between IL-15 and body composition in cancer patients.

We used the criterion of weight loss $\geq 10 \%$ to define cachexia (1). The present series includes a heterogeneous group of tumors, patients were included at the time of diagnosis of cancer, and mean duration of weight loss of about 11 weeks was shorter than mean duration of 24 weeks reported in a previous study (1). For this reason, only $38.1 \%$ of cancer patients met two of the three criteria of cachexia. Weight loss $\geq 10 \%$ was the main criterion for differentiating patients with and without cachexia since the inflammatory status, level of appetite, and caloric intake were similar. For this reason, weight loss per se was considered the fundamental criterion of cachexia, which is consistent with new definition of cachexia that uses weight loss $\geq 5 \%$ as the defining criterion $(2,21)$. However, when this new criterion was used, no differences in body weight or serum IL-15 levels at baseline and at follow-up were observed (data not shown).

In healthy subjects, serum levels of IL-15 found in our study are similar than those reported by others (22-28), although our subjects were older $(22,25,26)$. In ultralongeval subjects (>95 years), concentrations of IL-15 higher than in other age groups have been described (25). Lamana et al (29) analysed the serum IL-15 levels in 161 healthy subjects. Serum IL-15 levels did not follow a normal distribution, there was a higher frequency of values close o zero, the median serum IL-15 value was $0.83 \mathrm{pg} / \mathrm{ml}$ and there was no clear circadian rhythm. Also, there was no difference in the serum IL-15 values according to gender and they did not correlate with age. Serum IL-15 levels above $20 \mathrm{pg} / \mathrm{ml}$ were considered high (90th percentile of the healthy population). In cancer patients, no differences in baseline IL-15 levels according to the stage or extension of the disease have been reported $(30,31)$. In general, baseline IL-15 levels in cancer patients and controls published in the literature are higher than values observed in the present study (30-33).On the other hand, especially elevated mean baseline IL-15 concentrations have been reported in patients with hepatocarcinoma infected by the hepatitis $C$ virus $(77.4 \mathrm{pg} / \mathrm{ml})$ and in patients with mycosis fungoides $(94.2 \mathrm{pg} / \mathrm{ml})(32,33)$. In a series of patients with recent diagnosis of epidermoid carcinoma of the head and neck, IL-15 was not detected (34), and in 50 patients with non-Hodgkin lymphoma, levels of IL-15 before bone marrow transplantation were $8.75 \mathrm{pg} / \mathrm{ml}$ but IL-15 levels were undetectable in 27 control subjects (35). These differences as compared with our study may be due to the fact that these studies were not performed at the time of cancer diagnosis $(30,32,33,35)$ and that histology, age of the patients (31-33,35), laboratory assay (26), and lower levels of detection of IL-15 may be also different $(30,32,33,35)$.

Although, some thresholds of IL-15 levels have been associated with higher survival rates in patients with non-Hodgkin lymphoma and acute B-cell lymphocytic leukaemia $(35,36)$, we found differences in nutritional status and body composition in cancer patients for a threshold of $2 \mathrm{pg} / \mathrm{ml}$. Kuczynski et al (37) analyzed serum IL-15 concentrations in 51 type 1 diabetic patients. Diabetic patients with higher IL-15 serum levels ( $>6 \mathrm{pg} / \mathrm{ml}$ ) had higher HbA1c values, but differences between diabetic patients varying in IL-15 serum levels in BMI, serum CRP levels or lipid profile were not observed. In previous studies in healthy subjects, postmenopausal women, and dialysis patients increases in IL-15 concentrations were unrelated to body composition, muscle mass or muscle strength $(22,23,27,38,39)$. However, no comparative clinical studies of the relationship of cutpoints of serum IL-15 levels with nutritional and body composition parameters in cancer patients have been carried out.

IL-15 has an anti-adipose effect by inhibiting lipoprotein lipase (LPL) activity and de novo lipogenesis. In vivo models, the administration of IL-15 produced a 33\% decrease in fat tissue with a $20 \%$ decrease of circulating triglycerides without affecting caloric intake. A direct effect of muscular IL-15 on adipose tissue (muscle-to-fat endocrine axis) has been postulated mediated by the presence in adipose tissue of the three subunits of the IL-15 receptor (IL-15R) (40-42). Nielsen et al (28) showed a negative association between IL-15 and body fat mass, which was independent of the diagnosis of diabetes type 2 . There were no relationships between IL-15 and plasma lipids. In our study, cancer patients with baseline IL-15 concentrations $\geq 2 \mathrm{pg} / \mathrm{ml}$ showed lower values of fat mass throughout the study period. These findings suggest a physiopathologic anti-adipose role of IL-15 by inhibiting lipogenesis and stimulating fat mass depletion associated to cancer weight loss. Moreover, IL-15 could be a marker of inflammatory state and fat mass content in cancer patients who lose weight.

In our experience, cancer patients who gained weight at the end of the study also showed an increase in IL-15 levels at weeks 4 and 8 . Increases in body weight were related to an increase in muscle mass (64\%), whereas cancer patients who lose weight, weight loss was related to a decrease in fat mass 
(61\%). Changes in serum IL-15 levels showed a direct relationship with changes in body weight, BMI, fat-free mass and muscle mass, and an indirect association with the percentage of weight loss. The fact that these associations were not found in healthy subjects support that these changes are specific of cancer patients. These findings are consistent with the anabolic effects of IL-15 observed in experimental studies (10-15). Comparative studies in humans with cancer and weight loss are not currently available. However, chemotherapy is the natural treatment of cancer, and cancer patients who gained weight at the end of the study also received a higher number of cycles of chemotherapy as compared with patients who lost weight. Chemotherapy has been associated in patients with recurrent ovarian and breast cancer, and metastatic melanoma with lymphodepletion. Lymphodepletion in these patients was also associated with increased serum levels of the lymphocyte homeostatic cytokines IL-17 and IL-15 $(43,44)$. In our study, changes in serum IL-15 levels at 8 weeks as compared with baseline were indirectly associated with changes in lymphocyte count. Furthermore, diagnostic or therapeutic surgery cause a delay in the initiation of chemotherapy and produce and additional catabolic stress. Consequently, surgery can also promote weight loss. In our study, cancer patients who were treated surgically lost weight at 8 week and received a lesser number of cycles of chemotherapy. Thus, weight gain and serum IL-15 increase at the end of the study could be related with chemotherapy and absence of surgical treatment in these patients. In this way, IL-15 could play a possible role as a marker of weight and body composition response to chemotherapy in cancer patients and weight loss.

Insulin resistance and hypercortisolism are present in cachexia $(2,4)$. Studies in rat isolated skeletal muscles suggest that the main mechanism involved in the anabolic effects of IL-15 in skeletal muscle relies on a decrease in the proteolytic rate (45). In animals models of cancer cachexia, the protective effect of IL-15 on skeletal muscle proteolysis was nor mediated by corticosteroids and insulin and was due to inhibition of the gene expression of the ATP-ubiquitin-dependent proteasome system (12). The increase in glucocorticoids in patients with cachexia may contribute to proteolysis by stimulation of the ubiquitin-dependent proteasome activity and to difficult protein synthesis diverting amino acids and oligopeptides to hepatic synthesis of acute phase reactants (4). In the present study, an association between IL-15 and insulin was not observed. During the course of the study, however, cancer patients showed significantly higher basal insulin concentrations $(\mathrm{P}=0.07)$ and lower insulin sensitivity $(\mathrm{P}=0.041)$ than healthy subjects (data not shown). Patients who gained weight at the end of the study had higher basal cortisol levels than patients who lost weight (24.8 vs. $15.7 \mu \mathrm{g} / \mathrm{dl}, \mathrm{P}=0.043)$. In these patients, a decrease in cortisol levels $(-34.6 \%)$ and an indirect association between IL-15, cortisol, and CRP were observed at the end of the study. A direct relationship between IL-15 and amino acids was not observed. However, patients with baseline IL-15 levels $<2 \mathrm{pg} / \mathrm{ml}$ showed higher values of regulatory amino acids (such as histidine, tryptophan, and proline) and patients with weight gain at the end of the study showed increased concentrations of essential amino acids and leucine $(\mathrm{P}=0.015$ and $\mathrm{P}=0.002$, data not shown). The regulatory effect of some of these amino acids may also contribute to inhibi- tion of hepatic autophagy proteolysis (46). Leucine is the main branched-chain amino acid that regulates protein synthesis in skeletal muscle via insulin-dependent and -independent signalling pathway and inhibition of proteasome ubiquitindependent proteolysis system (47). This suggests that weight gain in cancer patients is a complex process that does not depend upon a single metabolic pathway (48).

Limitations of the study include the small sample size and the heterogeneity of patients. We used leg-to-leg impedance, which is a validated technique to measure body composition and to assess changes during weight loss (49). Patients older than 65 years of age were excluded to prevent age-associated sarcopenia $(2,50)$. Cancer patients with cachexia as compared with healthy subjects showed different body composition at baseline for two reasons. Firstly, 50\% of healthy subjects were women, whereas all cancer patients with cachexia were men. Sexual dimorphism in body composition (51) is evident from adolescence onwards. Apparently, this has not influenced the results because serum baseline IL-15 levels in healthy subjects are not influenced by the gender (29). Secondly, cancer patients with cachexia as compared with healthy subjects had previously a higher weight ( 84.7 vs. $68.5 \mathrm{~kg}, \mathrm{P}=0.036$ ), with increased fat and muscle mass. Since weight loss in cancer patients with cachexia is initially at the expense of fat, this could also explain the different body composition between this group of patients and healthy subjects. The weaknesses of the studies that measure cytokine levels and relate them to the pathogenesis of diseases have been avoided by measuring IL-15 levels at baseline and throughout the evolution of 8 weeks (52). In addition, the low serum IL-15 levels found in this study are not surprising if we bear in mind that cytokines act in an autocrine or paracrine manner with high concentrations at sites of release but decrease their concentrations after dilution in blood. A short half-life or their binding to molecules may difficult their detection by immunological methods (52). Further research is needed to study muscle IL-15 mRNA and muscle IL-15 protein from muscle biopsies, simultaneously with serum IL-15 concentrations, in cancer patients who lose weight (28).

In summary, in middle-aged patients with a recent cancer diagnosis and weight loss, serum IL-15 levels at baseline were not different between cancer patients and healthy subjects. Therefore, our results do not exclude the role of IL-15 in cancer weight loss (cachexia) physiopathology because, during evolution, serum IL-15 levels were indirectly associated with percentage of weight loss and directly associated with body composition in these patients. It would be interesting to investigate the relation between chemotherapy, weight changes and serum IL-15 levels before establishing the anabolic role (anti-cachexia) and the therapeutic potential of this cytokine (53).

\section{Acknowledgements}

This study was partially supported by a grant from the Fundación Mutua Madrileña. The authors are indebted to Rosario Madero Jarabo for the statistical support, Carmen Palma Milla, MD, for assistance in biochemical analyses, Professor Juan García Puig for his encouragement and valuable comments, Francisco Gayá Moreno for the figure support, and Marta Pulido, MD, freelance author editor for editing 
the manuscript and editorial assistance. The fees of medical editing were supported by Abbott España.

\section{References}

1. Fearon KC, Voss AC and Hustead DS: Definition of cancer cachexia: effect of weight loss, reduced food intake, and systemic inflammation on functional status and prognosis. Am J Clin Nutr 83: 1345-1350, 2006.

2. Evans WJ, Morley JE, Argilés J, Bales C, Baracos V, Guttridge D, Jatoi A, Kalantar-Zadeh K, Lochs H, Mantovani G, et al Cachexia: a new definition. Clin Nutr 27: 793-799, 2008

3. Tisdale MJ: Pathogenesis of cancer cachexia. J Support Oncol 1: $159-168,2003$.

4. Morley JE, Thomas DR and Wilson MMG: Cachexia: pathophysiology and clinical relevance. Am J Clin Nutr 83: 735-743, 2006

5. Dewys WD, Begg C, Lavin PT, Band PR, Bennett JM, Bertino JR, Cohen MH, Douglass HO Jr, Engstrom PF, Ezdinli EZ, et al: Prognostic effect of weight loss prior to chemotherapy in cancer patients. Eastern Cooperative Oncology Group. Am J Med 69: 491-497, 1980

6. Haehling S and Anker SD: Cachexia as a major underestimated and unmet medical need: facts and nunber. J Cachexia Sarcopenia Muscle 1: 1-5, 2010

7. Grabstein K, Eisenman J, Shanebeck K, Rauch C, Srinivasan S, Fung V, Beers C, Richardson J, Schoenborn MA, Ahdieh M, et al: Cloning of a $\mathrm{T}$ cell growth factor that interacts with the $\beta$ chain of the interleukin-2 receptor. Science 264: 965-968, 1994.

8. Burton JD, Bamford RN, Peters C, Grant AJ, Kurys G, Goldman CK, Brennan J, Roessler E and Waldmann TA: A lymphokine, provisionally designed interleukin $\mathrm{T}$ and produced by a human adult T-cell leukemia line, stimulates T-cell proliferation and the induction of lymphokine-activated killer cells. Proc Natl Acad Sci USA 91: 4935-4939, 1994.

9. Giri JG, Ahdieh M, Eisenman J, Shanebeck K, Grabstein K, Kumaki S, Namen A, Park LS, Cosman D and Anderson D: Utilization of the beta and gamma chains of the IL-2 receptor by the novel cytokine IL-15. EMBO J 13: 2822-2830, 1994

10. Quinn LS, Haugk KL and Grabstein KH: Interleukin-15: a novel anabolic cytokine for skeletal muscle. Endocrinology 136: 3669-3672, 1995.

11. Quinn LS, Anderson BG, Drivdahl RH, Alvarez B and Argilés JM: Overexpression of interleukin-15 induces skeletal muscle hypertrophy in vitro: implications for treatment of muscle wasting disorders. Exp Cell Res 280: 55-63, 2002.

12. Carbó N, López-Soriano J, Costelli P, Busquets S, Alvarez B, Baccino FM, Quinn LS, López-Soriano FJ and Argilés JM Interleukin-15 antagonizes muscle protein waste in tumourbearing rats. Br J Cancer 83: 526-531, 2000.

13. Van Royen M, Carbó N, Busquets S, Alvarez B, Quinn LS, López-Soriano FJ and Argilés JM: DNA fragmentation occurs in skeletal muscle during tumor growth: a link with cancer cachexia? Biochem Biophys Res Commun 270: 533-537, 2000.

14. Figueras M, Busquets S, Carbó N, Barreiro E, Almendro V, Argilés JM and López-Soriano FJ: Interleukin-15 is able to suppress the increased DNA fragmentation associated with muscle wasting in tumour-bearing rats. FEBS Lett 569: 201-206, 2004.

15. Busquets S, Almendro V, Barreiro E, Figueras M, Argilés JM and López-Soriano FJ: Activation of UCPs gene expression in skeletal muscle can be independent on both circulating fatty acids and food intake. Involvement of ROS in a model of mouse cancer cachexia. FEBS Lett 579: 717-722, 2005.

16. Zubrod CG, Scheneidermann M, Frei E, Brindley C, Gold GL, Shnider B, Oviedo R, Gorman J, Jones R Jr, Jonsson U, et al: Appraisal of methods for the study of chemotherapy of cancer in man: comparative therapeutic trial of nitrogen mustard and trietylene thiophosphoramide. J Chron Dis 11: 7-33, 1960.

17. Utter AC, Nieman DC, Ward AN and Butterworth DE: Use of the leg-to-leg bioelectrical impedance method in assessing body-composition change in obese women. Am J Clin Nutr 69: 603-607, 1999.

18. Ordóñez A, Feijoo M and González Barón M: Evaluación de la Astenia. In: Valoración clínica del paciente con cáncer. González Barón M, Lacasta MA and Ordóñez A (eds). Editorial Médica Panamericana, S.A. Madrid, pp79-87, 2006.
19. ATS Committee on Proficiency Standards for Clinical Pulmonary Function Laboratories: ATS statement: guidelines for the six-minute walk test. Am J Respir Crit Care Med 166: $111-117,2002$.

20. Katz A, Nambi SS, Mather K, Baron AD, Follmann DA, Sullivan G and Quon MJ: Quantitative insulin sensitivity check index: a simple, accurate method for assessing insulin sensitivity in humans. J Clin Endocrinol Metab 85: 2402-2410, 2000.

21. Fearon K, Strasser F, Anker SD, Bosaeus I, Bruera E, Fainsinger RL, Jatoi A, Loprinzi C, MacDonald N, Mantovani G, et al: Definition and classification of cancer cachexia: and international consensus. Lancet Oncol 12: 489-495, 2011.

22. Lambert CP, Flynn MG, Sullivan DH and Evans WJ: Effects of megestrol acetate on circulating interleukin-15 and interleukin-18 concentrations in healthy elderly men. J Gerontol A Biol Sci Med Sci 59: 855-858, 2004

23. Riechman SE, Balasekaran G, Roth SM and Ferrel RE: Association of interleukin-15 protein and interleukin-15 receptor genetic variation with resistance exercise training responses. $\mathrm{J}$ Appl Physiol 97: 2214-2219, 2004.

24. Spatari G, Fenga C, Minciullo PL, Di Pasquale G, Cacciola A, Ventura-Spagnolo E and Gangemi S: Modification of interleukin-15 serum levels in workers exposed to chemotherapeutic agents. Mediators Inflamm 1: 60-62, 2005.

25. Gangemi S, Basile G, Monti D, Merendino RA, Di Pasquale G, Bisignano U, Nicita-Mauro V and Franceschi C: Age-related modifications in circulating IL-15 levels in humans. Mediators Inflamm 4: 245-247, 2005

26. Yamaji K, Nabeshima S, Murata M, Chong Y, Furusyo N, Ikematsu $H$ and Hayashi J: Interferon- $\alpha / \beta$ upregulate IL-15 expression in vitro and in vivo: analysis in human hepatocellular carcinoma cell lines and in chronic hepatitis $\mathrm{C}$ patients during interferon- $\alpha / \beta$ treatment. Cancer Immunol Immunother 55: 394-403, 2006.

27. Nielsen AR, Mounier R, Plomgaard P, Mortensen OH, Penkowa M, Speerschneider T, Pilegaard $\mathrm{H}$ and Pedersen BK: Expression of interleukin-15 in human skeletal muscle-effect of excercise and muscle fibre type composition. J Physiol 584: 305-312, 2007

28. Nielsen AR, Hojman P, Erikstrup C, Fischer CP, Plomgaard P, Mounier R, Mortensen OH, Broholm C, Taudorf S, KroghMadsen R, et al: Association between interleukin-15 and obesity: interleukin-15 as a potential regulator of fat mass. J Clin Endocrinol Metab 93: 4486-4493, 2008.

29. Lamana A, Ortiz AM, Alvaro-Gracia JM, Díaz-Sánchez B, Novalbos J, García-Vicuña R and González-Alvaro I: Characterization of serum interleukin-15 in healthy volunteers and patients with early arthritis to assess its potential use as a biomarker. Eur Cytokine Netw 21: 186-194, 2010.

30. Lissoni P, Rovelli F, Mandala M and Barni S: Blood concentrations of interleukin-15 in cancer patients and their variations during interleukin-2 immunotherapy: preliminary considerations. Int J Biol Markers 13: 169-171, 1998.

31. Pappa C, Miyakis S, Tsirakis G, Sfiridaki A, Alegakis A, Kafousi M, Stathopoulos EN and Alexandrakis MG: Serum levels of interleukin-15 and interleukin-10 and their correlation with proliferating cell nuclear antigen in multiple myeloma. Cytokine 37: 171-175, 2007.

32. Kakumu S, Okumura A, Ishikawa T, Yano M, Enomoto A, Nishimura H, Yoshioka K and Yoshika Y: Serum levels of IL-10, IL-15 and soluble tumour necrosis factor-alpha (TNF- $\alpha$ ) receptors in type C chronic liver disease. Clin Exp Immunol 109: 458-463, 1997.

33. Sugaya M, Nakamura K and Tamaki K: Serum interleukin-15 levels are not elevated in patients with stage I and II mycosis fungoides. Acta Derm Venereol 80: 455, 2000.

34. Badoual C, Bouchand G, Agueznay NEH, Mortier E, Hans S, Gey A, Fernani F, Peyrard S, Laurent-Puig P, Bruneval P, et al: The soluble alpha chain of interleukin-15 receptor: a proinflammatory molecule associated with tumor progression in head and neck cancer. Cancer Res 68: 3907-3914, 2008.

35. Porrata LF, Inwards DJ, Micallef IN, Johnston PB, Ansell SM, Hogan WJ and Markovic SN: Interleukin-15 affects patient survival through natural killer cell recovery after autologous hematopoietic stem cell transplantation for non-Hodgkin lymphomas. Clin Dev Immunol doi: 10.1155/2010/914945, 2010.

36. Wu S, Fischer L, Gökbuget N, Schwartz S, Burmeister T, Notter M, Hoelzer D, Fuchs H, Blau IW, Hofmann WK and Thiel E: Expression of interleukin-15 in primary adult acute lymphoblastic leukemia. Cancer 116: 387-392, 2010. 
37. Kuczynski S, Winiarska H, Abramczyck M, Szczawinska K, Wierusz-Wysocka B and Dworacka M: IL-15 is elevated in serum patients with type 1 diabetes mellitus. Diabetes Res Clin Pract 69: 231-236, 2005.

38. Prestes J, Shiguemoto G, Botero JP, Frollini A, Dias R, Leite R, Pereira G, Magosso R, Baldissera V, Cavaglieri C and Perez S: Effects of resistance training on resistin, leptin, cytokines, and muscle force in elderly post-menopausal women. J Sports Sci 27: 1607-1615, 2009

39. Grzegorzewska AE, Mlot M and Leander M: Serum levels of cancer antigen 125 and interleukin-15 in relation to the nutrition status of peritoneal dialysis patients. Adv Perit Dial 20: 185-189, 2004.

40. Carbó N, López-Soriano J, Costelli P, Alvarez B, Busquets S, Baccino FM, Quinn LS, López-Soriano FJ and Argilés JM: Interleukin-15 mediates reciprocal regulation of adipose and muscle mass: a potential role in body weight control. Biochim Biophys Acta 1526: 17-24, 2001.

41. Alvarez B, Carbó N, López-Soriano J, Drivdahl RH, Busquets S, López-Soriano FJ, Argilés JM and Quinn LS: Effects of interleukin-15 (IL-15) on adipose tissue mass in rodent obesity models: evidence for direct IL-15 action on adipose tissue. Biochim Biophys Acta 1570: 33-37, 2002.

42. Quinn LS, Strait-Bodey L, Anderson BG, Argilés JM and Havel PJ: Interleukin-15 stimulates adiponectin secretion by 3T3-L1 adipocytes: evidence for a skeletal muscle-to-fat signalling pathway. Cell Biol Int 29: 449-457, 2005.

43. Geller MA, Cooley S, Judson PL, Ghebre R, Carson LF, Argenta PA, Jonson AL, Panoskaltsis-Mortari A, Curtsinger J, McKenna D, et al: A phase II study of allogeneic natural killer cell therapy to treat patients with recurrent ovarian and breast cancer. Cy totherapy 13: 98-107, 2011.

44. Dudley ME, Yang JC, Sherry R, Hughes MS, Royal R, Kammula U, Robbins PF, Huang JP, Citrin DE, Leitman SF, et al: Adoptive cell therapy for patients with metastatic melanoma: evaluation of intensive myeloablative chemoradiation preparative regimens. J Clin Oncol 26: 5233-5239, 2008.
45. Busquets S, Figueras MT, Meijsing S, Carbó N, Quinn LS, Almendro V, Argilés JM and López-Soriano FJ: Interleukin-15 decreases proteolysis in skeletal muscle: a direct effect. Int J Mol Med 16: 471-476, 2005.

46. Kadowaki $\mathrm{M}$ and Kanazawa T: Amino acids as regulators of proteolysis. J Nutr 133: S2052-S2056, 2003.

47. Garlick PJ: The role of leucine in the regulation of protein metabolism. J Nutr 135: S1553-S1556, 2005.

48. Mitch WE and Goldberg AL: Mechanisms of muscle wasting The role of the ubiquitin-proteasome pathway. N Engl J Med 335: 1897-1905, 1996.

49. Thomson R, Brinkworth GD, Buckley JD, Noakes M and Clifton PM: Good agreement between bioelectrical impedance and dual-energy X-ray absorptiometry for estimating changes in body composition during weight loss in overweight young women. Clin Nutr 26: 771-777, 2007.

50. Evans WJ: Skeletal muscle loss: cachexia, sarcopenia, and inactivity. Am J Clin Nutr 91: S1123-S1127, 2010.

51. Malina RM: Variation in body composition associated with sex and ethnicity. In: Human Body Composition. Heymsfield SB Lohman TG, Wang ZM and Going SB (eds). 2nd edition. McGraw-Hill Interamericana Editores, S.A. Mexico, pp271-298, 2007.

52. Rentzos M, Paraskevas GP, Kapaki E, Nikolaou C, Zoga M, Tsoutsou A, Rombos A and Vassilopoulos D: Circulating interleukin-15 in dementia disorders. J Neuropsychiatry Clin Neurosci 19: 318-325, 2007.

53. Argilés JM, López-Soriano FJ and Busquets S: Therapeutic potential of interleukin-15: a myokine involved in muscle wasting and adiposity. Drug Discov Today 14: 208-213, 2009. 